\title{
Peran Keluarga dalam Mencegah Terjadinya Adverse Event pada Pasien di Rumah Sakit
}

\author{
Afna Saharani \\ afnasaharani1412@gmail.com
}

\section{Latar Belakang}

Keselamatan Pasien (Patient Safety) merupakan sesuatu yang jauh lebih penting dari pada sekedar efisiensi pelayanan. Perilaku perawat dengan kemampuan perawat sangat berperan penting dalam pelaksanaan keselamatan pasien. Perilaku yang tidak aman, lupa, kurangnya perhatian/motivasi, kecerobohan, tidak teliti dan kemampuan yang tidak memperdulikan dan menjaga keselamatan pasien berisiko untuk terjadinya kesalahan dan akan mengakibatkan cedera pada pasien, berupa Near Miss (Kejadian Nyaris Cedera/KNC) atau Adverse Event (Kejadian Tidak Diharapkan/KTD) selanjutnya pengurangan kesalahan dapat dicapai dengan memodifikasi perilaku. Perawat harus melibatkan kognitif, afektif dan tindakan yang mengutamakan keselamatan pasien. World Health Organization (WHO), 2014 Keselamatan pasien merupakan masalah keseahatan masyarakat global yang serius. Di Eropa mengalami pasien dengan resiko infeksi 83,5\% dan bukti kesalahan medis menunjukkan 50-72,3\%. Di kumpulkan angka-angka penelitian rumah sakit di berbagai Negara, ditemukan KTD dengan rentang 3,2 -16,6\%.

Bawelle, 2013 secara keseluruhan program patient safety sudah diterapkan, namun masalah dilapangan merujuk pada konsep patient safety, karena walaupun sudah pernah mengikuti sosialisasi, tetapi masih ada pasien cedera, resiko jatuh, resiko salah pengobatan, pendelegasian yang tidak akurat saat oforan pasien yang mengakibatkan keselamatan pasien menjadi kurang maksimal.

Rumah sakit harus mendidik pasien dan keluarganya tentang kewajiban dan tanggung pasien dalam asuhan kesehatan pasien. Keselamatan pasien dalam pemberian pelayanan dapat di tingkatkan dengan keterlibatan pasien yang merupakan patner dalam proses pelayanan. Karena itu di rumah sakit harus ada sistem dan mekanisme mendidik pasien dan keluarganya tentang kewajiban dan tanggung jawab pasien dalam asuhan pasien. 


\section{Metode}

Metode penelitian yang digunakan adalah metode research dan analisis dari berbagai sumber yaitu jurnal print, jurnal online, text book, dan skripsi dengan membandingkan beberapa bahan bacaan yang berhubungan dengan Peran Keluarga dalam Mencegah Terjadinya Adverse Event pada Pasien di Rumah Sakit.

\section{Hasil}

Dari hasil penelitian melalui metode research dan analitik ini, pengetahuan mengenai Peran Keluarga dalam Mencegah Terjadinya Adverse Event pada Pasien di Rumah Sakit yaitu Rumah sakit harus memiliki sistem dan mekanisme mendidik pasien dan keluarganya tentang kewajiban dan tanggung jawab pasien dalam asuhan pasien. Untuk mengambil tindakan, pasien dan keluarganya harus terlebih dahulu paham terkait tindakan yang akan diambil dan konsekuensi pelayanan yang akan diambil.

Berdasarkan Permenkes RI Nomor 11 Tahun 2017 tentang Keselamatan Pasien bahwa keselamatan dalam memberikan pelayanan dapat ditingkatkan dengan keterlibatan pasien yang merupakan partner dalam proses pelayanan. Oleh karena itu, maka fasilitas kesehatan harus memiliki sistem dan mekanisme mendidik pasien dan keluarganya mengenai kewajiban dan tanggungjawab dalam asuhan pasien. Dengan pendidikan tersebut diharapkan pasien dan keluarganya dapat berpartisipasi dengan baik, dan mendapat informasi dalam mengambil keputusan tentang asuhan yang diterimanya.

Pemberian informasi yang diberikan oleh dokter penanggung jawab pelayanan kepada pasien dan keluarga harus dilakukan dengan lengkap karena pasien berhak mengetahui tentang penyakit yang sedang dia derita, harus jujur karena hal tersebut berkaitan dengan nyawa pasien itu sendiri benar dan jelas karena dokter tidak berhak menambah-nambah ataupun mengurangi informasi yang akan diberikan kepada pasien. Dalam hal ini dokter maupun petugas kesehatan lain yang memberikan penjelasan harus menjelaskan dengan pelan-pelan karena kondisi pasien maupun keluarganya yang berbeda-beda misalnya ada yang penerima dan ada yang tidak menerima mengenai kondisinya tersebut. 


\section{Pembahasan}

Penerapan enam sasaran keselamatan pasien dan peran keluarga dalam menjaga keselamatan pasien di rumah sakit.

\section{Ketepatan Identifikasi Pasien}

Pasien dalam keadaan tidak sadar, gelisah, mengalami gangguan penglihatan, gangguan pendengaran, gangguan proses pikir, mendapat obat bius, atau gangguan lain tidak mampu melakukan identifikasi diri dengan benar selain itu pasien yang pindah ruang rawat atau bertukar tempat tidur saat perawatan di rumah sakit berisiko mengalami ketidaktepatan identifikasi, maka rumah sakit menyusun sistem untuk memastikan identifikasi pasien sebagai individu yang akan menerima pelayanan adalah tepat dan jenis pelayanan atau pengobatan terhadap individu tersebut adalah sesuai.

Peran Pasien dan keluarga untuk memastikan ketepatan identifikasi pasien adalah:

a. Memberikan data diri yang tepat pada saat mendaftar sesuai dokumen data diri yang dimiliki. Data utama yang diperlukan adalah nama dan tanggal lahir.

b. Selama rawat inap pasien dipakaikan gelang. Pasien dan keluarga harus memahami fungsi gelang dan patuh menggunakan gelang tersebut selama rawat inap karena gelang tersebut dipakai oleh tim kesehatan guna memastikan kebenaran identitas dan faktor risiko pasien saat memberikan pelayanan.

1. Gelang warna biru untuk laki-laki dan gelang warna merah muda untuk perempuan dipakai untuk identifikasi.

2. Gelang warna merah dipasangkan pada pasien yang memiliki riwayat alergi

3. Gelang warna kuning dipasangkan pada pasien yang memiliki risiko jatuh 
c. Pasien atau keluarga kooperatif saat dilakukan verifikasi identitas oleh petugas saat akan melakukan tindakan, memberikan obat, mengambil preparat untuk pemeriksaan laborat dan lain-lain.

\section{Komunikasi Efektif}

Pasien yang menjalani rawat inap dikelola oleh dokter dan berbagai profesi lain sebagai tim dengan menerapkan sistem komunikasi yang efektif untuk memberikan pelayanan. Peran pasien dan keluarga mewujudkan komunikasi efektif adalah:

a.Menunjuk atau menetapkan anggota keluarga yang diberi kewenangan untuk berkomunikasi dengan tim kesehatan. Penunjukkan ini diperlukan untuk memastikan komunikasi berlangsung efektif dan berkesinambungan, tidak mengalami rantai komunikasi yang panjang dan kompleks yang berisiko menyebabkan perubahan makna isi informasi.

b.MemberikanMemberikan informasi dan data terkait kondisi pasien kepada tim kesehatan dengan benar dan jelas.

c. MemberikanMemberikan informasi pada petugas bila ada kejadian tidak diharapkan.

d. MemintaMeminta informasi yang diperlukan kepada tim kesehatan

\section{Pemberian Obat Secara Aman}

Pemberian obat merupakan bagian yang mengambil porsi dominan dalam tata kelola pasien rawat inap. Peran serta keluarga dalam menjamin keamanan pemberian obat adalah :

a. Memberikan informasi yang lengkap tentang riwayat obat yang pernah dipergunakan sebelum masuk rumah sakit

b. Memberikan informasi tentang riwayat alergi atau reaksi yang dialami saat menggunakan obat tertentu

c. Mendukung pengawasan pemberian obat selama rawat inap dengan cara memastikan identitas pasien benar, menanyakan jenis obat yang diberikan, tujuan pemberian, dosis dan waktu pemberian obat 


\section{Kepastian Tepat-Lokasi, Tepat-Prosedur, Tepat-Pasien Operasi}

Tindakan operasi merupakan salah satu prosedur yang mungkin dilakukan pada pasien untuk mengatasi masalah kesehatannya. Bagian tubuh yang akan dioperasi bisa meliputi bagian yang bersisi (misalnya tangan atau kaki kanan dan kiri, mata kanan dan kiri) atau bagian yang multipel level (misalnya tulang belakang) atau bagian yang multipel struktur (misalnya jari tangan) dengan demikian diterapkan sistem untuk memastikan tindakan tepat-lokasi, tepatprosedur, tepat-pasien

Salah satu prosedur yang dilakukan sebelum tindakan operasi adalah proses verifikasi. Peran pasien dan keluarga dalam proses verifikasi praoperasi adalah memberikan informasi yang benar dan bekerja sama secara kooperatif Proses yang dilakukan meliputi :

a. Verifikasi lokasi, prosedur, dan pasien yang benar

Proses ini dilakukan dengan membuat tanda pada lokasi yang dioperasi. Penandaan lokasi operasi ini melibatkan pasien, dibuat oleh dokter yang akan melakukan tindakan dan dilaksanakan saat pasien dalam keadaan sadar .Tanda ini tidak boleh dihapus dan harus terlihat sampai saat akan disayat.

a. Memastikan bahwa semua dokumen, foto (imaging), hasil pemeriksaan yang relevan tersedia, diberi label dengan baik

b. Melakukan verifikasi ketersediaan peralatan khusus yang dibutuhkan.

\section{Pengurangan Risiko infeksi Terkait Pelayanan Kesehatan}

Rumah sakit merupakan tempat yang memungkinkan berkumpulnya berbagai jenis kuman sedangkan pasien yang sedang dirawat memiliki daya tahan tubuh relatif rendah dengan demikian diperlukan suatu proses bersama untuk mencegah timbulnya infeksi lain yang tidak berhubungan dengan penyakit utama pasien. Peran pasien dan keluarga dalam pengurangan risiko terkait pelayanan kesehatan adalah 
a. Menerapkan prosedur cuci tangan yang benar

Keluarga memiliki kemungkinan sering kontak dengan pasien, maka untuk melindungi diri sendiri dan melindungi pasien dari perpindahan kuman disarankan keluarga menerapkan prosedur cuci tangan yang benar pada 5 (lima) momen yaitu saat sebelum kontak dengan pasien, sesudah kontak pasien, sesudah ke toilet, sebelum dan sesudah makan.

Perlu diperhatikan juga bahwa lingkungan sekitar pasien berisiko terpapar kuman maka disarankan mencuci tangan sesudah kontak dengan lingkungan pasien (meja, alat tenun, tempat tidur dsb). Guna memperoleh hasil cuci tangan yang optimal Pasien dan keluarga disarankan mencermati dan mengikuti petunjuk 6 (enam) langkah mencuci tangan yang diberikan oleh petugas atau panduan cuci tangan yang ada di rumah sakit.

b. Membatasi pengunjung pasien

Selama pasien dirawat di rumah sakit seyogyanya pasien tidak berinteraksi dengan banyak orang karena berisiko terpapar kuman dari pengunjung dalam keadaan pertahanan diri yang relatif rendah dengan demikian peran keluarga diperlukan untuk membatasi pengunjung yang kontak dengan pasien.

c.Menerapkan etika batuk yang benar

Keluarga dan pengunjung yang batuk berisiko menyebarkan kuman melalui partikel halus di udara dengan demikian bila sedang mengalami batuk keluarga perlu menggunakan masker atau menerapkan tehnik perlindungan yang benar saat batuk yaitu menutup mulut dan hidung menggunakan lengan.

\section{Pengurangan Risiko Pasien Jatuh}

Individu yang sedang sakit memiliki keterbatasan dalam pengamanan diri termasuk menghindari jatuh. Rumah sakit mengambil tindakan untuk mengurangi risiko dengan melakukan pengkajian faktor-faktor yang dapat menyebabkan jatuh seperti, penggunaan obat, 
gaya jalan dan keseimbangan, alat bantu berjalan yang digunakan oleh pasien, riwayat jatuh saat berjalan atau saat istirahat baring di tempat tidur.

Peran pasien dan keluarga dalam mencegah jatuh saat dirawat di rumah sakit adalah :

a. Pastikan penanda pasien beresiko jatuh berupa gelang kuning dipakai pasien

b. Jangan melepas atau memindah kartu kuning yang dipasang petugas dekat tempat tidur pasien atau di depan kamar pasien karena kartu tersebut merupakan penanda untuk mewaspadai pasien yang beresiko jatuh

c. Keluarga atau pasien perlu memastikan diri untuk memahami informasi yang diberikan oleh petugas agar dapat mendukung tindakan pencegahan jatuh. Informasi yang perlu diketahui adalah:

- faktor resiko jatuh yang teridentifikasi seperti obat yang dipergunakan, kesadaran pasien, keseimbangan saat berjalan,dll

- tindakan pencegahan jatuh yang perlu dilakukan

- cara untuk minta bantuan

- cara menggunakan bel atau sarana komunikasi di ruangan

- cara mengatur pengamanan tempat tidur

- pengggunaan tali pengaman, dll

Pengelolaan pasien rawat inap tidak hanya mejadi tanggung jawab tim kesehatan tetapii melibatkan juga pribadi pasien sendiri dan keluarga, maka setiap bagian perlu menjalankan peran masing-masing sesuai tugasnya karena proses kerja sama yang baik merupakan dasar yang kuat untuk memperoleh hasil optimal. 


\section{Daftar Pustaka}

Simamora, R. H. (2019). Buku ajar pelaksanaan identifikasi pasien. Uwais Inspirasi Indonesia.

Nabillah, Abubakar,. \& Nilamsari, Neffrety. (2017). Pengetahuan dan Sikap Keluarga Pasien

Rawat Inap Rumah Sakit Haji Surabaya . Jurnal manajemen kesehatan universitas Airlangga vol 3 no 1.

Fitrawati,. Pabuty,. \& Putra. (2012). Pelaksanaan Program Keselamatan Pasien di RSUD Solok. Jurnal Kesehatan Masyarakat vol 6 no 2.

Iskandar, Edy. (2017). Tata Kelola dan Kepatuhan Penerapan Standar Patient Safety Penyakit Stroke di Rumah Sakit Dr.Kanujoso Djatiwibowo Tahun 2015. Jurnal ARSI fakultas kesehatan masyarajat universitas Indonesia vol 3 no 3.

Juniarti Nanda Hani, Ahmad Agid Mudayana (2018). Penerapan Standar Keselamatan Pasien Di Rumah Sakit Umum Daerah Provinsi Nusa Tenggara Barat. Jurnal kesehatan poltekes Ternate, vol 11 no 2.

Syam, Nur. (2017). Implementasi Budaya Keselamatan Pasien Oleh Perawat di Rumah Sakit Ibnu Sina Makasar. Jurnal fakultas kesehatan masyarajat universitas Indonesia vol 11 no 2

Priyoto, Widyastuti.(2014). Kebutuhan Dasar Keselamatan Pasien. Jogjakarta: Graha Ilmu.

Pujilestari, Maidin, Anggraeni. (2013).Gambaran Budaya Keselamatan Pasien Oleh Perawat Dalam Melaksanakan Pelayanan di Instalasi Rawat Inap RSUP dr.Wahidin Sudirohusodo. Jurnal keperawatan,vol 10 no 1,74-105.

Fitriana, Yuni,. \& Pratiwi, Kurniasari. (2018). Pelaksanaan Patient Safety Di Rumah Sakit Umum Daerah Dan Rumah Sakit Umum Swasta Bantul Berdasarkan Ketentuan Undang-Undang nomor 44 Tahun 2009 Tentang Rumah Sakit. Jurnal Akademi Kebidanan Yogyakarta, vol 7 no 1 . 
Yusuf, Muhammad. (2017). Penerapan Patient Safety Di Ruang Rawat Inap Rumah Sakit Umum Daerah Dr. Zainoel Abidin. Jurnal keperawatan Universitas Syiah Kuala, vol 5 no 1

Tutiany, Lindawati, Paula Krisanti. (2017). Manajemen Keselamatan Pasien. Jakarta: Kementrian Kesehatan Republik Indonesia. 